\title{
An annotated checklist of the freshwater cladocerans (Crustacea: Branchiopoda: Cladocera) of Ecuador and the Galápagos Islands
}

\author{
C. López ${ }^{1,2}$, P.V. Mosquera ${ }^{3}$, H. Hampel ${ }^{4,5}$, A.N. Neretina ${ }^{6 *}$, \\ M. Alonso ${ }^{7}$, K. Van Damme ${ }^{8}$, A.A. Kotov ${ }^{6,9}$ \\ ${ }^{1}$ Escuela Superior Politécnica del Litoral, ESPOL, Facultad de Ciencias de la Vida y Centro del \\ Agua y Desarrollo Sustentable, Campus Gustavo Galindo, Km. 30.5, Via Perimetral, Guayaquil \\ 090101, Ecuador.E-mail: cllopez@espol.edu.ec \\ ${ }^{2}$ Departamento de Biología, Facultad Experimental de Ciencias, Universidad del Zulia, Avenida \\ Universidad, Sector Grano de Oro, Maracaibo 4005, Venezuela. \\ ${ }^{3}$ Subgerencia de Gestión Ambiental de la Empresa Pública Municipal de Telecomunicaciones, \\ Agua potable, Alcantarillado y Saneamiento (ETAPA EP),Benigno Malo y Sucre, Cuenca, Ecua- \\ dor.E-mail: pmosquerav@gmail.com \\ ${ }^{4}$ Laboratorio de Ecología Acuática, Departamento de Recursos Hidricos y Ciencias Ambientales, \\ Universidad de Cuenca, Av. 12 de Abril S/N, Cuenca, Ecuador.E-mails: hennihampel@gmail.com; \\ henrietta.hampel@ucuenca.edu.ec \\ ${ }^{5}$ Facultad de Ciencias Químicas, Universidad de Cuenca, Av. 12 de Abril S/N, Cuenca, Ecuador. \\ ${ }^{6}$ Laboratory for Ecology of Aquatic Communities and Invasions, A.N. Severtsov Institute of Ecology \\ and Evolution, Russian Academy of Sciences, Leninsky Prospect 33, Moscow 119071, Russia. E- \\ mail: neretina-anna2017@yandex.ru \\ ${ }^{7}$ Departament de Biologia Evolutiva, Ecologia i Ciències Ambientals, Universitat de Barcelona, \\ Av.Diagonal 643,08028 Barcelona, Spain.E-mail: malonso@ub.edu \\ ${ }^{8}$ Senckenberg Research Institute, Senckenberganlage 25, Frankfurt a.M. 60325, Germany. E-mail: \\ kay.vandamme@gmail.com \\ ${ }^{9}$ Laboratory of Paleoclimatology, Kazan Federal University, Kremlevskaya Street 18, Kazan \\ 420000, Russia. E-mail: alexey-a-kotov@yandex.ru
}

ABSTRACT: An annotated checklist of recorded species of Cladocera (Crustacea: Branchiopoda) from inland aquatic habitats in Ecuador (including the Galápagos) is provided. We revised all published records, evaluated the validity of each taxon and provided short taxonomic and biogeographical remarks for each taxon. A total of 34 valid species grouped into 23 genera was found. Presently, all attempts to analyze distributional patterns of cladocerans in Ecuador are premature due to the scarcity of adequate information. Current achievements in the inventory of cladocerans, information gaps and recommendations for future studies on cladoceran taxonomy in Ecuador are discussed.

How to cite this article: López C., Mosquera P.V., Hampel H., Neretina A.N., Alonso M., Van Damme K., Kotov A.A. 2018. An annotated checklist of the freshwater cladocerans (Crustacea: Branchiopoda: Cladocera) of Ecuador and the Galápagos Islands // Invert. Zool. Vol.15. No.3. P.277-291. doi: 10.15298/invertzool.15.3.06

KEY WORDS: checklist, Cladocera, biodiversity, Neotropics, South America, taxonomy. 


\title{
Аннотированный список пресноводных ветвистоусых ракообразных (Crustacea: Branchiopoda: Cladocera) Эквадора и Галапагосских островов
}

\author{
К. Лопез ${ }^{1,2}$, П.В. Москера ${ }^{3}$, Г. Хампель Х,5 $^{4}$ А.Н. Неретина $6^{6}$, \\ М. Алонсо ${ }^{7}$ К. Ван Дамме 8 , А.А. Котов ${ }^{6,9}$
}

${ }^{1}$ Escuela Superior Politécnica del Litoral, ESPOL, Facultad de Ciencias de la Vida y Centro del Agua y Desarrollo Sustentable, Campus Gustavo Galindo, Km. 30.5, Via Perimetral, Guayaquil 090101,Ecuador.E-mail: cllopez@espol.edu.ec

${ }^{2}$ Departamento de Biología, Facultad Experimental de Ciencias, Universidad del Zulia, Avenida Universidad, Sector Grano de Oro, Maracaibo 4005, Venezuela.

${ }^{3}$ Subgerencia de Gestión Ambiental de la Empresa Pública Municipal de Telecomunicaciones, Agua potable, Alcantarillado y Saneamiento (ETAPA EP), Benigno Malo y Sucre, Cuenca, Ecuador.E-mail: pmosquerav@gmail.com

${ }^{4}$ Laboratorio de Ecología Acuática, Departamento de Recursos Hídricos y Ciencias Ambientales, Universidad de Cuenca, Av. 12 de Abril S/N, Cuenca,Ecuador.E-mails: hennihampel@gmail.com; henrietta.hampel@ucuenca.edu.ec

${ }^{5}$ Facultad de Ciencias Químicas, Universidad de Cuenca, Av. 12 de Abril S/N, Cuenca, Ecuador.

6 Лаборатория экологии водных сообществ и инвазий, Инститкт проблем экологии и эволючии им. А.Н. Севериова РАН, Ленинский проспект 33, Москва 119071, Россия. E-mail: neretina-anna2017@yandex.ru

${ }^{7}$ Departament de Biologia Evolutiva, Ecologia i Ciuncies Ambientals, Universitat de Barcelona, Av. Diagonal 643,08028 Barcelona, Spain.E-mail: malonso@ub.edu

${ }^{8}$ Senckenberg Research Institute, Senckenberganlage 25, Frankfurt a.M. 60325, Germany. E-mail: kay.vandamme@gmail.com

9 Лаборатория палеоклиматологии, Казанский (Приволжский) федеральный университет, ул. Кремлевская 18, Казань 420000, Республика Татарстан, Россия. E-mail: aleхеу-аkotov@yandex.ru

РЕЗЮМЕ: В статье представлен аннотированный список видов ветвистоусых ракообразных (Crustacea: Branchiopoda), отмеченных во внутренних водоемах Эквадора и Галапагосских островов. Мы пересмотрели все опубликованные находки, проанализировали валидность каждого таксона и привели короткие таксономические и биогеографические примечания для каждого таксона. Всего нами было выявлено 34 валидных вида кладоцер, принадлежащих к 23 родам. В настоящее время, любые попытки анализа паттернов распределения ветвистоусых ракообразных в Эквадоре являются преждевременными из-за нехватки надежной информации. Также в статье обсуждены текущие достижения в области инвентаризации кладоцер, информационные пробелы и приведены рекомендации для будущих исследований по систематике кладоцер Эквадора.

Как цитировать эту статью: López C., Mosquera P.V., Hampel H., Neretina A.N., Alonso M., Van Damme K., Kotov A.A. 2018. An annotated checklist of the freshwater cladocerans (Crustacea: Branchiopoda: Cladocera) of Ecuador and the Galápagos Islands // Invert. Zool. Vol.15. No.3. P.277-291. doi: 10.15298/invertzool.15.3.06

КЛЮЧЕВЫЕСЛОВА: контрольный список, Cladocera, биоразнообразие, Неотропики, Южная Америка, систематика.

\footnotetext{
*Автор для переписки
} 


\section{Introduction}

Investigations of the cladocerans (Crustacea: Branchiopoda: Cladocera) of the inland freshwater bodies of South America began at the end of the 19th century and were initially carried out by European taxonomists (e.g. Ihering, 1895; Sars, 1901; Stingelin, 1913; Delachaux, 1919; Brehm, 1956). Studies of the freshwater cladocerans of Ecuador began much later. Only at the beginning of the 1980s, some pioneer surveys were carried out as a part of limnological studies on the Galápagos Islands and Andean lakes (e.g. Colinvaux, SteinitzKannan, 1980). Since the 1980s only a handful of papers recorded the cladocerans from the inland waters of Ecuador (Gunkel, 2000; Casallas, Gunkel, 2001; Torres, Rylander, 2006; Obando, 2009; Briones, 2012; López-Blanco, Sinev, 2016; Van Colen et al., 2017; Alonso et al., 2017; Alonso, Kotov, 2017; Alonso, Sinev, 2017) have appeared. Compared to other countries in the tropical zone of South America (Valdivia Villar, 1988; Elmoor-Loureiro, 1998; 2000; Zoppi de Roa, López, 2008; Kotov, Fuentes-Reinés, 2015), the taxonomic knowledge on the cladocerans of Ecuador is limited. Such studies are now just beginning.

National and regional checklists are crucial for a basic knowledge on the biodiversity and such efforts allow a firm taxonomical basis for derived studies. Recently, several comprehensive checklists with taxonomical notes have been compiled for different countries where cladocerans are under intense study, e.g. India (Chatterjee et al., 2013), China (Korovchinsky, 2013; Ji et al., 2015; Xiang et al., 2015) and Korea (Jeong et al., 2014) in Asia; Colombia (Kotov, Fuentes-Reinés, 2015), Chile (De los Ríos Escalante, Kotov, 2015) and Brazil (Elmoor-Loureiro, 1998, 2018) in South America. At the same time, large revisions and checklists in Cladocera genera have helped to tackle taxonomical challenges (e.g. Van Damme et al., 2010).

The aims of the present paper are to provide a formal list of the Ecuadorian (including the Galápagos Archipelago) cladocerans based on all available literature, to evaluate the validity of all recorded species and to discuss some taxonomic and biogeographical issues. Moreover, we identify information gaps and provide recommendations for future investigations of taxonomy and biogeography of the cladocerans of Ecuadorian inland waters.

\section{Material and methods}

The list of the cladocerans of Ecuador compiled herein is based on data from literature, a revision of all published papers we could find to date. Species listed for Ecuador are discussed with special attention to their taxonomic status. Current valid species names and combinations are based on the FADA checklist (Kotov et al., 2013), with some exclusions specified below. The species are attributed to three geographic and physiographic provinces of the continental territory of this country: Andean Region, Coastal Region, Amazonian Region according to Steere (1950) and to the Galápagos Islands (Fig. 1).

\section{Results}

In total, 34 valid species of Cladocera have been reported in literature from inland water bodies of Ecuador. These species belong to seven families and 23 genera. The family Chydoridae, as expected, includes the largest number of genera (13 genera) followed by the Daphniidae ( 3 genera). The remaining families each contain two or one genera. Chydoridae includes 15 species, followed by Daphniidae (12 species), Macrothricidae (2 species), Ilyocryptidae (2 species), Sididae (2 species), Bosminidae (2 species) and Moinidae (1 species).

\section{Order Ctenopoda Sars, 1865}

\section{Family Sididae Baird, 1850} 1848)

(1) Diaphanosoma brachyurum (Liévin,

Records. Coastal Region: Chongón Reservoir $\left(02^{\circ} 13^{\prime} 09^{\prime \prime} \mathrm{S} 80^{\circ} 07^{\prime} 32^{\prime \prime} \mathrm{W}\right), 54 \mathrm{~m}$ a.s.1., Province of Guayas (Briones, 2012). 


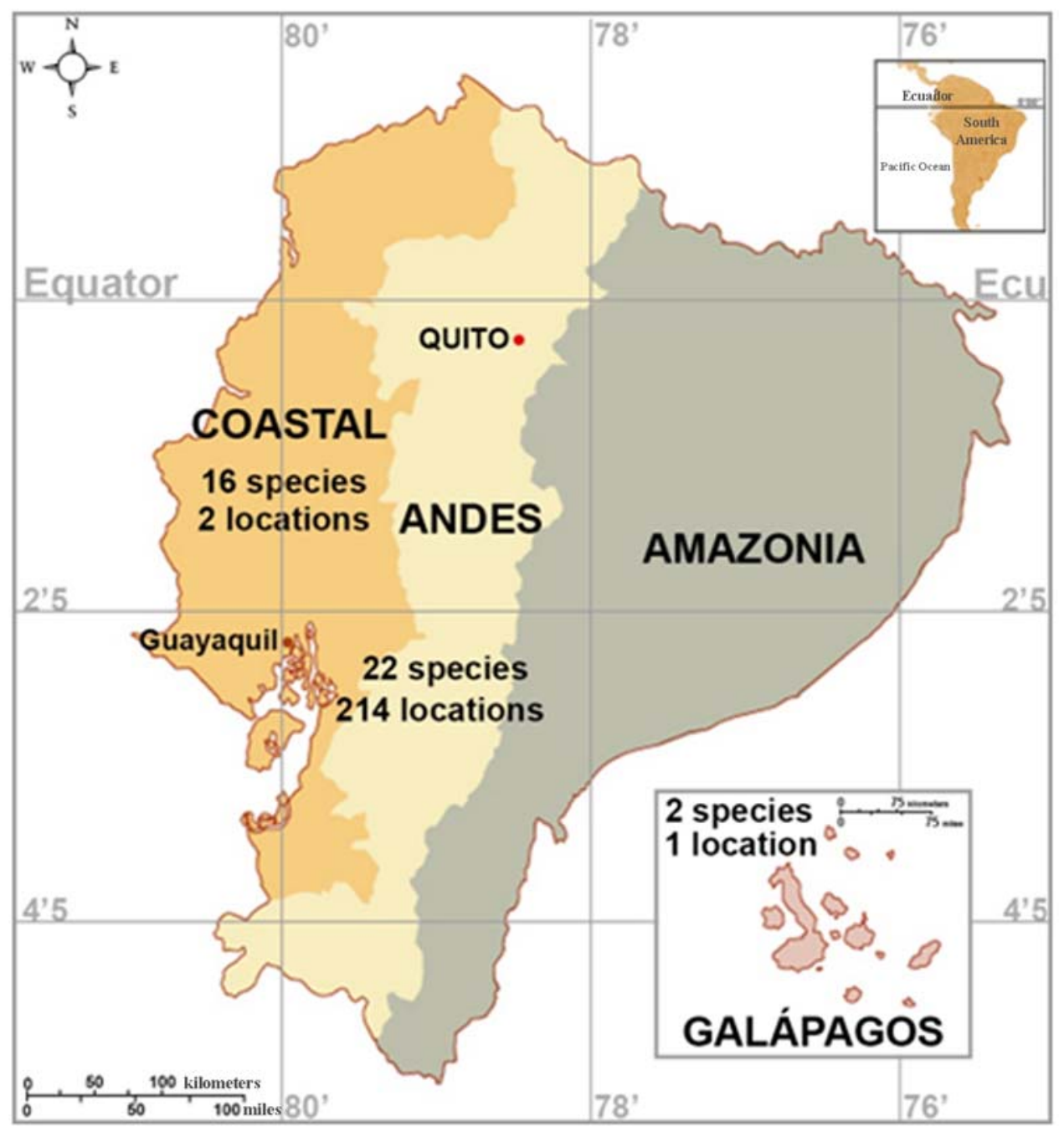

Fig. 1. Map of Ecuador showing main geographical regions, number of recorded species and number of sampled locations in each region.

Рис. 1. Карта Эквадора с обозначенными основными биогеографическими районами, число выявленных видов и число обследованных водоемов приведено для каждого региона.

Taxonomical remarks. D. brachyurum has been originally described from Europe and constitutes a complex of cryptic species with several related taxa in the Nearctic and Neotropical regions (Korovchinsky, 1992, 2004). Often, existing reports of this taxon refers to other species, even in Europe (Korovchinsky, 2000). In the Neotropics, this name is used incorrectly because this species in absent in South America (Korovchinsky, 2004). The Ecuadorian popula- tions need to be revised and all Neotropical records of this species must be critically evaluated. As a result, this common and diverse tropical species group remains unresolved in Ecuador.

\section{(2) Sarsilatona serricauda Sars, 1901}

Records. Coastal Region: Lake Tembladera ( $\left.3^{\circ} 29^{\prime} 29^{\prime \prime} \mathrm{S} 79^{\circ} 59^{\prime} 40^{\prime \prime} \mathrm{W}\right), 17 \mathrm{~m}$ a.s.l., Province of El Oro, identified on remains in lake sediments (López-Blanco, Sinev, 2016). 
Taxonomical remarks. S. serricauda was described from Brazil (see Korovchinsky, 2004). It is distributed from the southern U.S.A. to northern Argentina (Korovchinsky, 2004; Kotov, Fuentes-Reinés, 2015).

\section{Order Anomopoda Sars, 1865}

\section{Family Daphniidae Straus, 1820}

(1) Ceriodaphnia cf. cornuta Sars, 1885

Records. Coastal Region: Chongón Reser$\operatorname{voir}\left(02^{\circ} 13^{\prime} 09^{\prime \prime} \mathrm{S} 80^{\circ} 07^{\prime} 32^{\prime \prime} \mathrm{W}\right), 54 \mathrm{~m}$ a.s.1., Province of Guayas (Briones, 2012).

Taxonomical remarks. This taxon was initially described from Australia (Sars, 1885) and then found in other tropical regions. Now it is considered as a complex of closely related species, specific for each continent (Sharma, Kotov, 2013). According to DNA-barcoding data, the C. cornuta species complex harbors cryptic species in tropical regions of the Neotropics as well (Elías-Gutiérrez et al., 2008). C. cornuta, sometimes listed under the name of its African congener, C. rigaudi Richard 1894, is commonly recorded in the region (Valdivia Villar, 1988; Elmoor-Loureiro, 2000; Zoppi de Roa, López, 2008; Kotov, Fuentes-Reinés, 2015). Although nowadays taxonomists consider this species as a complex of sibling taxa, $C$. cf. cornuta can be easily distinguished from other Ceriodaphnia species based on its prominent rostrum. Neotropical populations need to be revised in detail as part of a global revision of this group.

(2) Ceriodaphnia dubia Richard, 1894

Records. Andean Region: Lakes of Cajas National Park ( $\left.2^{\circ} 50^{\prime} 00^{\prime \prime} \mathrm{S} 79^{\circ} 10^{\prime} 00^{\prime \prime} \mathrm{W}\right), 3.160$ $4.450 \mathrm{~m}$ a.s.1., Province of Azuay (Alonso et al., 2017).

Taxonomical remarks. C. dubia is initially described from Indonesia, but then found in different regions of the world with tropical and temperate climate (see Chatterjee et al., 2013). It has been reported from Andean lakes in nearby countries (Zoppi de Roa, López, 2008; De los Ríos Escalante, Kotov, 2015; Kotov, Fuentes-Reinés, 2015). This taxon needs a global revision, as it is apparently a group of closely related species (e.g. Sharma, 2014).

\section{(3) Daphnia (Daphnia) ambigua Scourf-} ield, 1947

Records. Andean Region: Lakes of Reserva Ecológica Cayambe-Coca (Páramo de Guamaní) $\left(0^{\circ} 21^{\prime} 00^{\prime \prime} \mathrm{S} 78^{\circ} 12^{\prime} 00^{\prime \prime} \mathrm{W}\right)$ (Torres, Rylander, 2006). Lakes of Cajas National Park ( $2^{\circ} 50^{\prime} 00^{\prime \prime} \mathrm{S}$ $\left.79^{\circ} 10^{\prime} 00^{\prime \prime} \mathrm{W}\right), 3.160-4.450 \mathrm{~m}$ a.s.l. Province of Azuay (Alonso et al., 2017). Lake Colta $\left(1^{\circ} 45^{\prime} 00^{\prime \prime} \mathrm{S} 78^{\circ} 44^{\prime} 33^{\prime \prime} \mathrm{W}\right), 3.288 \mathrm{~m}$ a.s.1. (Villalobos, 1994).

Taxonomical remarks. The taxon was initially described from the United Kingdom, but the description was based on an exotic population occurring out of its main distribution range in the New World (see Benzie, 2005). This small-sized species of Daphnia is distributed throughout the Americas (Matsumura-Tundisi, 1984, Adamowicz et al., 2004; Benzie, 2005) and invaded Europe. South American populations form a distinct clade (Hebert et al., 2003). It could be confused with $D$. parvula, which has been also recorded from Ecuador.

(4) Daphnia (Daphnia) laevis Birge, 1879

Records. Andean Region: Lakes of Cajas National Park ( $\left.2^{\circ} 50^{\prime} 00^{\prime \prime S} 79^{\circ} 10^{\prime} 00^{\prime \prime} \mathrm{W}\right) \cdot 3 \cdot 160$ $4.450 \mathrm{~m}$ a.s.l., Province of Azuay (Alonso et al., 2017).

Taxonomical remarks. This taxon was initially described from U.S.A. (see Benzie, 2005). It represents a group of cryptic species distributed in North and South America and Africa (Taylor et al., 1998; Adamowicz et al., 2004; Benzie, 2005).

(5) Daphnia (Daphnia) longispina (O.F. Müller, 1776)

Records. Andean Region: Lakes of Cajas National Park ( $\left.2^{\circ} 50^{\prime} 00^{\prime \prime} \mathrm{S} 79^{\circ} 10^{\prime} 00^{\prime \prime} \mathrm{W}\right), 3.160$ $4.450 \mathrm{~m}$ a.s.1., Province of Azuay (Labaj et al., 2017; Van Colen et al., 2017).

Taxonomical remarks. D. longispina was initially described from Denmark (see Kotov, 2015). This morphological confusing species complex has a wide geographical distribution in Africa, Europe and Asia (Benzie, 2005, Kotov et al., 2013). Its taxonomy is confused even in Europe (Petrusek et al., 2008; Kotov, 2015). As D. longispina s.str. does not occur in South America (Adamowicz et al., 2004), this is most likely a misidentification. 


\section{5}

(6) Daphnia (Daphnia) cf. obtusa Kurz,

Records. Andean Region: Lakes of Cajas National Park ( $\left.2^{\circ} 50^{\prime} 00^{\prime \prime} \mathrm{S} 79^{\circ} 10^{\prime} 00^{\prime \prime} \mathrm{W}\right), 3.160$ $4.450 \mathrm{~m}$ a.s.1., Province of Azuay (Alonso et al., 2017).

Taxonomical remarks. Daphnia obtusa was initially described from Czech Republic (see Benzie, 2005). It is considered now a nearly cosmopolitan complex of species with numerous species (Benzie, 2005). Populations assigned to D. obtusa s.l. have been reported from high altitude regions of different tropical countries (Villalobos, 1994; Kotov, Taylor, 2010; Van Damme, Eggermont, 2011). Populations are known from the Neotropics (Villalobos, 1994). In South America this species needs to be revised, it is apparently represented by a series of taxa even on this continent (Kotov, Taylor, 2010).

(7) Daphnia (Daphnia) parvula (Fordyce, 1901)

Records. Andean Region: Lakes of Cajas National Park ( $\left.2^{\circ} 50^{\prime} 00^{\prime \prime S} 79^{\circ} 10^{\prime} 00^{\prime \prime} \mathrm{W}\right), 3.160$ 4.450 m a.s.l., Province of Azuay (Alonso et al., 2017).

Taxonomical remarks. D. parvula has been described for North America, but has a wide geographical range in the western hemisphere, especially latitudinal (Benzie, 2005; Popova, Kotov, 2013), and widely distributed in Europe (Alonso, 1996; Flössner, 2000). This taxon could be confused with $D$. ambigua, which is also present in our checklist.

\section{0}

(8) Daphnia (Daphnia) cf. pulex Leydig,

Records. Andean Region: Lake San Pablo $\left(0^{\circ} 12^{\prime} 00^{\prime \prime} \mathrm{N} 78^{\circ} 13^{\prime} 00^{\prime \prime} \mathrm{E}\right), 2.660$ m.a.s.1., Province of Imbabura (Gunkel, 2000; Labaj et al., 2017). Cajas National Park $\left(2^{\circ} 50^{\prime} 00^{\prime \prime} \mathrm{S} 79^{\circ}\right.$ $\left.10^{\prime} 00^{\prime \prime} \mathrm{W}\right), 3.160-4.450 \mathrm{~m}$ a.s.l., Province of Azuay (Alonso et al., 2017).

Taxonomical remarks. It was initially described from unknown locality in Europe (Benzie, 2005). This taxon is a complex of species and a revision of the group is needed (Kotov, Taylor, 2010; Kotov, 2016), in particular for populations from South America (Crease et al., 2012) and may be confused with $D$. pulicaria.

\section{(9) Daphnia (Daphnia) pulicaria Forbes,} 1893

Records. Andean Region: Lake San Pablo $\left(0^{\circ} 12^{\prime} 00^{\prime \prime} \mathrm{N} 78^{\circ} 13^{\prime} 00^{\prime \prime} \mathrm{E}\right), 2.660 \mathrm{~m}$ a.s.1., Province of Imbabura (Villalobos, 1998; Casallas, Gunkel, 2001). Lake Coicochoa $\left(0^{\circ} 18^{\prime} 00^{\prime \prime} \mathrm{N}\right.$ $\left.78^{\circ} 21^{\prime} 00^{\prime \prime} \mathrm{W}\right), 3.246 \mathrm{~m}$ a.s.1. (Villalobos, 1994). Cajas National Park $\left(2^{\circ} 50^{\prime} 00^{\prime \prime} \mathrm{S} 79^{\circ} 10^{\prime} 00^{\prime \prime} \mathrm{W}\right)$, 3.160-4.450 m a.s.1., Province of Azuay (Alonso et al., 2017).

Taxonomical remarks. This taxon was initially described from U.S.A. (see Benzie, 2005). According to Adamowicz et al. (2004) some records of $D$. pulex in South America may refer to D. pulicaria, and both taxa are easily confused also in Europe (see also in Crease et al. (2012)).

(10)Simocephalus acutifrons Johnson, 1953

Records. Coastal Region: Chongón Reser$\operatorname{voir}\left(02^{\circ} 13^{\prime} 09^{\prime \prime} \mathrm{S} 80^{\circ} 07^{\prime} 32^{\prime \prime} \mathrm{W}\right), 54$ ma.s.1., Province of Guayas (Briones, 2012).

Taxonomical remarks. This species was described from the Republic of South Africa (see Orlova-Bienkowskaja, 2001). Then it was considered as a junior synonym of $S$. brehmi Gauthier, 1939 (Orlova-Bienkowskaja, 2001; Kotov et al., 2013). Both taxa were described from the African continent (Gauthier, 1939; Johnson, 1953) and populations of $S$. cf. brehmi have been reported from Brazil (Orlova-Bienkowskaja, 2001; Van Damme, Dumont, 2010). This is a very easily recognizable taxon, yet the status in South American populations needs revision (Van Damme, Dumont, 2010). The Ecuadorian record needs revision in comparison to other Neotropical populations of $S$. cf. brehmi.

\section{(11) Simocephalus exspinosus (De Geer,} 1778)

Records. Galápagos Islands: Lake El Junco $\left(0^{\circ} 53^{\prime} 42^{\prime \prime} \mathrm{S} 89^{\circ} 28^{\prime} 48^{\prime \prime} \mathrm{W}\right), 675$ m a.l.s., San Cristóbal Island (Obando, 2009).

Taxonomical remarks. The species was initially described from Europe, now it is considered as cosmopolitan taxon (Orlova-Bienkowskaja, 2001) which needs a global revision.

(12) Simocephalus cf. vetulus (O.F. Müller, 1776)

Records. Coastal Region: Chongón Reservoir $\left(02^{\circ} 13^{\prime} 09^{\prime \prime} \mathrm{S} 80^{\circ} 07^{\prime} 32^{\prime \prime} \mathrm{W}\right), 54 \mathrm{~m}$ a.s.l., Prov- 
ince of Guayas (Briones, 2012). Andean Region: Lakes of Cajas National Park $\left(2^{\circ} 50^{\prime} 00^{\prime \prime} \mathrm{S}\right.$ $\left.79^{\circ} 10^{\prime} 00^{\prime \prime} \mathrm{W}\right), 3.160-4.450 \mathrm{~m}$ a.s.1., Province of Azuay (Alonso et al., 2017).

Taxonomical remarks. S. vetulus is a Palearctic species initially described from Denmark (see Orlova-Bienkowskaja, 2001; Huang et al., 2014). Unfortunately, Orlova-Bienkowskaja (2001) did not analyze material from South America. According to Kotov et al. (2010), S. vetulus or a very closely related species is present in this continent. Neotropical populations of this taxon need to be checked morphologically and genetically, keeping in mind the existence of numerous vetulus-like species in other regions of the world (Huang et al., 2014).

Family Moinidae Goulden, 1968

(1) Moina micrura Kurz, 1874

Records. Coastal Region: Chongón Reservoir $\left(02^{\circ} 13^{\prime} 09^{\prime \prime} \mathrm{S} 80^{\circ} 07^{\prime} 32^{\prime \prime} \mathrm{W}\right), 54 \mathrm{~m}$ a.s.l., Province of Guayas (Briones, 2012).

Taxonomical remarks. The species was initially described from Czech Republic (see Petrusek et al., 2004). This taxon represents a cosmopolitan group which needs a detailed global revision (Elías-Gutiérrez et al., 1999; Petrusek et al., 2004; Bekker et al., 2016).

Family Ilyocryptidae Smirnov, 1976 sensu Smirnov, 1992

(1) Ilyocryptus spinifer Herrick, 1882

Records. Coastal Region: Chongón Reser$\operatorname{voir}\left(02^{\circ} 13^{\prime} 09^{\prime \prime} \mathrm{S} 80^{\circ} 07^{\prime} 32^{\prime \prime} \mathrm{W}\right), 54 \mathrm{~m}$ a.s.l., Province of Guayas (Briones, 2012).

Taxonomical remarks. This species was initially described from U.S.A. (see Kotov, Dumont, 2000). It is a common tropicopolitan taxon, usually found in different localities in South America (Kotov, Dumont, 2000).

(2) Ilyocryptus spinosus (Štifter, 1988)

Records. Andean Region: Lakes of Cajas National Park ( $\left.2^{\circ} 50^{\prime} 00^{\prime \prime S} 79^{\circ} 10^{\prime} 00^{\prime \prime} \mathrm{W}\right), 3.160$ $4.450 \mathrm{~m}$ a.s.l., Province of Azuay (recorded by Alonso et al., 2017).

Taxonomical remarks. This species was initially described from Germany (see Kotov, Štifter, 2006). I. spinosus has been reported from the Northwest of U.S.A, Northeast of Canada and the North of Europe (Kotov, Štifter,
2006). Ecuadorian populations should be compared morphologically and genetically with Neartic and Paleartic populations. The former could belong to a described taxon related to $I$. spinosus s.str.

Family Macrothricidae Norman and Brady, 1867

(1) Macrothrix cf. hirsuticornis (Norman and Brady, 1867)

Records. Andean Region: Lakes of Cajas National Park $\left(2^{\circ} 50^{\prime} 00^{\prime \prime} \mathrm{S} 79^{\circ} 10^{\prime} 00^{\prime \prime} \mathrm{W}\right), 3.160$ $4.450 \mathrm{~m}$ a.s.l., Province of Azuay (Alonso et al., 2017).

Taxonomical remarks. This species was initially described from the United Kingdom (see Kotov, 2007). According to Smirnov (1992), only Palearctic populations could be regarded as $M$. hirsuticornis s.str., yet this taxon was recorded from North and South America as well. Kotov (2007) concluded that all populations from southern South America belong to $M$. oviformis Ekman, 1900. The record from Ecuador and others from the Neotropics must be revised because its identity with $M$. oviformis is not obvious.

\section{(2) Drepanothrix dentata Eurén, 1861}

Records. Coastal Region: Chongón Reservoir $\left(02^{\circ} 13^{\prime} 09^{\prime \prime} \mathrm{S} 80^{\circ} 07^{\prime} 32^{\prime \prime} \mathrm{W}\right), 54 \mathrm{~m}$ a.s.l., Province of Guayas (Briones, 2012).

Taxonomical remarks. This species was initially described from Sweden (Smirnov, 1992). It is distributedin the Palearctic region only (Alonso, 1996; Flössner, 2000). This taxon may also be present in the Neartic region (Kotov et al., 2013). Drepanotrix dentata was considered by Kotov (2016) as a complex of species which needs to be revised taxonomically. Only Iglesias et al. (2016) recorded this species in South America previously. There is a high chance that populations from South America belong to a new species if it is not a misidentification.

Family Bosminidae Baird, 1845 sensu Sars, 1865

(1) Bosmina (Bosmina) longirostris (O.F. Müller, 1776)

Records. Andean Region: Cajas National Park ( $\left.2^{\circ} 50^{\prime} 00^{\prime \prime} \mathrm{S} 79^{\circ} 10^{\prime} 00^{\prime \prime} \mathrm{W}\right), 3.160-4.450 \mathrm{~m}$ a.s.1., Province of Azuay (Alonso et al., 2017). 
Taxonomical remarks. This taxon was initially described from Denmark; preliminary genetic data suggests that this is a really cosmopolitan taxon (Chatterjee et al., 2013).

(2) Bosmina (Liederobosmina) huaronensis Delachaux, 1918

Records. Andean Region: Lakes of Cajas National Park ( $\left.2^{\circ} 50^{\prime} 00^{\prime \prime} \mathrm{S} 79^{\circ} 10^{\prime} 00^{\prime \prime} \mathrm{W}\right), 3.160$ $4.450 \mathrm{~m}$ a.s.1., Province of Azuay (Alonso et al., 2017).

Remarks. This species is initially described from Peruvian Andes; it is widely distributed in the Americas (De los Ríos Escalante, Kotov, 2015).

\section{Family Chydoridae Dybowski and Gro- chowski, 1894}

(1) Acroperus tupinamba Sinev \& Elmoor-

\section{Loureiro 2010}

Records. Coastal Region: Lake Tembladera $\left(3^{\circ} 29^{\prime} 29^{\prime \prime} \mathrm{S} 79^{\circ} 59^{\prime} 40^{\prime \prime} \mathrm{W}\right), 17 \mathrm{~m}$ a.s.l., Province of El Oro, based on remains in lake sediments (López-Blanco, Sinev, 2016).

Remarks. A. tupinamba was described from Brazil; it has a wide distribution in Brazil and likely in other areas in the Neotropics (Sinev, Elmoor-Loureiro, 2010).

(2) Alona cf. affinis (Leydig, 1860)

Records. Andean Region: Lakes of Reserva Ecológica Cayambe-Coca (Páramo de Guamaní) $\left(0^{\circ} 21^{\prime} 00^{\prime \prime} \mathrm{S} 78^{\circ} 12^{\prime} 00^{\prime \prime} \mathrm{W}\right)$ (Torres, Rylander 2006).

Taxonomical remarks. The species was initially described from Germany (see Sinev, 1997). Any records from the New World are unlikely belong to European $A$. affinis s.str. To date, several New World populations have been assigned to existing as well as new names (Sinev, 1997; Van Damme et al., 2010). In Lake Titicaca (high altitudes of Peru), an A. affinis-like population has been given a name yet needs a formal redescription (see Van Damme et al., 2010). The record from Ecuador needs a revision; it probably refers to $A$. ossiani (Sinev, 1998). In this checklist $A$. affinis is considered a dubious record.

(3) Alona glabra Sars, 1901

Records. Andean Region: Lakes of Cajas National Park ( $\left.2^{\circ} 50^{\prime} 00^{\prime \prime S} 79^{\circ} 10^{\prime} 00^{\prime \prime} \mathrm{W}\right), 3.160$
$4.450 \mathrm{~m}$ a.s.1., Province of Azuay (Alonso et al., 2017).

Taxonomical remarks. The taxon was initially described from Argentina; this is a widespread Neotropical species (Sinev, 2001). But it deserves close attention, because there are at least two different phylogroups in the region (Elías-Gutiérrez et al., 2008). Sinev (2015a) recently revised this group (including Neotropical taxa) and suggested to move all $A$. pulchellarelated species to the genus Ovalona, proposing a new combination Ovalona glabra (Sars, 1901).

(4) Alona guttata Sars, 1862

Records. Andean Region: Lakes of Reserva Ecológica Cayambe-Coca (Páramo de Guamaní) $\left(0^{\circ} 21^{\prime} 00^{\prime \prime} \mathrm{S} 78^{\circ} 12^{\prime} 00^{\prime \prime} \mathrm{W}\right)$ (Torres, Rylander, 2006). Lakes of Cajas National Park ( $2^{\circ} 50^{\prime} 00^{\prime \prime} \mathrm{S}$ $\left.79^{\circ} 10^{\prime} 00^{\prime \prime} \mathrm{W}\right), 3.160-4.450 \mathrm{~m}$ a.s.1., Province of Azuay (Labaj et al., 2017).

Taxonomical remarks. This taxon was initially described from Norway; it represents a cosmopolitan complex of species, widely distributed, which needs to be revised worldwide (Van Damme et al., 2010). Neotropical populations show differences from North American species in this complex, A. barbulata, and from the European A. guttata (Sousa et al., 2016).

\section{(5) Alona ossiani (Sinev, 1998)}

Records. Andean Region: Lakes of Cajas National Park $\left(2^{\circ} 50^{\prime} 00^{\prime \prime} \mathrm{S} 79^{\circ} 10^{\prime} 00^{\prime \prime} \mathrm{W}\right), 3.160$ $4.450 \mathrm{~m}$ a.s.l., Province of Azuay (Alonso et al., 2017).

Taxonomical remarks. The taxon was described from Brazil (Sinev, 1998). A. ossiani is a Neotropical congener of the truly Palearctic $A$. affinis (Leydig, 1860) (Sinev, 1998; Van Damme et al., 2010; Sinev, 2013). The previous record of $A$. affinis from Ecuador reported by Torres and Rylander (2006) most likely belongs to $A$. ossiani or to another related species, not to $A$. affinis s.str., and should be checked in detail.

(6) Alpinalona cajasi Alonso \& Sinev, 2017

Records. Andean Region: Lakes of Cajas National Park ( $\left.2^{\circ} 50^{\prime} 00^{\prime \prime S} 79^{\circ} 10^{\prime} 00^{\prime \prime} \mathrm{W}\right), 3.160$ $4.450 \mathrm{~m}$ a.s.1., Province of Azuay (Alonso, Sinev, 2017).

Taxonomical remarks. Recorded initially by Alonso et al. (2017), as Alona sp. related to 
Alona manueli Sinev et Zawisza, 2013 (Alona sp. gr. manueli) (Sinev, Zawisza, 2013). It was described the same year as a new species in a new genus Alpinalona Alonso et Sinev, 2017.

\section{7}

(7) Alonella hampelae Alonso \& Kotov

Records. Andean Region: Lakes of Cajas National Park $\left(2^{\circ} 50^{\prime} 00^{\prime \prime} \mathrm{S} 79^{\circ} 10^{\prime} 00^{\prime \prime} \mathrm{W}\right), 3.160$ $4.450 \mathrm{~m}$ a.s.l. (Alonso, Kotov, 2017).

Taxonomical remarks. This taxon was recently described from Lakes of Cajas National Park (Ecuador) by Alonso and Kotov (2017). It belongs to the $A$. excisa-group. All records of $A$. cf. excisa of South America need revision because other taxa could be present there (Alonso, Kotov, 2017).

(8) Alonella nana Baird, 1843

Records. Coastal Region: Chongón Reser$\operatorname{voir}\left(02^{\circ} 13^{\prime} 09^{\prime \prime} \mathrm{S} 80^{\circ} 07^{\prime} 32^{\prime \prime} \mathrm{W}\right), 54 \mathrm{~m}$ a.s.l., Province of Guayas (in Briones (2012) as "Alona nana").

Taxonomical remarks. This taxon was initially described from the United Kingdom (see Smirnov, 1971). Briones (2012) recorded "Alona nana Baird 1843" which is an erroneous combination, the author apparently meant Alonella nana. However, A. nana does not occur in the Neotropics (Smirnov, 1996) and it is possible that the record of Briones (2012) has been confused with a small Neotropical taxon $A$. dadayi, which is recognizable by a long rostrum. This record in the lowlands of Ecuador may be invalid.

(9) Camptocercus dadayi (Stingelin, 1913)

Records. Andean Region: Cajas National Park ( $\left.{ }^{\circ} 50^{\prime} 00^{\prime \prime} \mathrm{S} 79^{\circ} 10^{\prime} 00^{\prime \prime} \mathrm{W}\right), 3.160-4.450 \mathrm{~m}$ a.s.1., Province of Azuay (Alonso et al., 2017).

Taxonomical remarks. C. dadayi is a welldefined Neotropical taxon initially described from Colombia (see Sinev, 2015b). 1776)

(10) Chydorus cf. sphaericus (O.F. Müller,

Records. Andean Region: Lakes of Reserva Ecológica Cayambe-Coca (Páramo de Guamaní) $\left(0^{\circ} 21^{\prime} 00^{\prime \prime} \mathrm{S} 78^{\circ} 12^{\prime} 00^{\prime \prime} \mathrm{W}\right)$ (Torres, Rylander, 2006). Coastal Region: Lake Tembladera ( $3^{\circ} 29^{\prime}$ $\left.29^{\prime \prime} \mathrm{S} 79^{\circ} 59^{\prime} 40^{\prime \prime} \mathrm{W}\right), 17 \mathrm{~m}$ a.s.1., Province of El Oro (López-Blanco, Sinev, 2016). Andean Re- gion: Lakes of Cajas National Park ( $2^{\circ} 50^{\prime} 00^{\prime \prime} \mathrm{S}$ $\left.79^{\circ} 10^{\prime} 00^{\prime \prime} \mathrm{W}\right), 3.160-4.450 \mathrm{~m}$ a.s.1., Province of Azuay (Alonso et al., 2017; Labaj et al., 2017).

Taxonomical remarks. The species was initially described from Denmark (Smirnov, 1971). This is a very difficult cosmopolitan species complex with many taxa, as revealed by genetic methods (Belyaeva, Taylor, 2009; Kotov et al., 2016). The name "C. sphaericus" is used for nearly every Chydorus around the world, and it is not certain that all these records belong to the C. sphaericus group. Any records of this difficult genus should be accompanied by drawings or photos for confirmation. 1982

(11) Ephemeroporus acanthodes Frey,

Records. Andean Region: Lakes of Reserva Ecológica Cayambe-Coca (Páramo de Guamaní) $\left(0^{\circ} 21^{\prime} 00^{\prime \prime} \mathrm{S} 78^{\circ} 12^{\prime} 00^{\prime \prime} \mathrm{W}\right)$ (Torres, Rylander, 2006, misspelled as "E. acanthoides").

Remarks. The species was initially described from souther U.S.A., in South America, it have been found in the Peruvian Andes (Valdivia Villar, 1988), a Venezuelan Andean lake (López, 1993) and more recently in different water bodies in Brazil (Serafim et al., 2003, Van Damme, Dumont, 2010) and Paraguay (Debastiani-Júnior et al., 2015). Several species of Ephemeroporus are present in the Neotropics, identifications should be checked thoroughly.

(12) Euryalona occidentalis Sars, 1901

Records. Galápagos Islands: Lake El Junco $\left(0^{\circ} 53^{\prime} 42^{\prime \prime} \mathrm{S} 89^{\circ} 28^{\prime} 48^{\prime \prime} \mathrm{W}\right), 675$ m a.s.1., San Cristóbal Island (Obando, 2009).

Taxonomical remarks. It is a clearly recognizable Neotropical taxon initially described from Brazil (Paggi, 1980).

(13) Kurzia cf. latissima (Kurz, 1875)

Records. Coastal Region: Chongón Reservoir $\left(02^{\circ} 13^{\prime} 09^{\prime \prime} \mathrm{S} 80^{\circ} 07^{\prime} 32^{\prime \prime} \mathrm{W}\right), 54 \mathrm{~m}$ a.s.1., Province of Guayas (Briones, 2012).

Taxonomical remarks. It was initially described from Czech Republic, its distribution is restricted to the Afrotropics and the Palearctic (Hudec, 2000). South American records have been shown to belong to K. polyspina (Hudec, 2000; Elmoor-Loureiro, 2002). It is most likely 
that identification of Briones 2012 is erroneous, and the author dealt with $K$. polyspina.

(14) Leydigiopsis brevirostris Brehm, 1938

Records. Coastal Region: Chongón Reser$\operatorname{voir}\left(02^{\circ} 13^{\prime} 09^{\prime \prime} \mathrm{S} 80^{\circ} 07^{\prime} 32^{\prime \prime} \mathrm{W}\right), 54 \mathrm{~m}$ a.s.1., Province of Guayas (Briones, 2012).

Taxonomical remarks. This is a well-defined Neotropical species initially described from Brazil (Sinev, 2004; Van Damme, Sinev, 2013), and other species in this genus can be expected in Ecuador.

(15) Magnospina dentifera (Sars, 1901)

Records. Coastal Region: Lake Tembladera $\left(3^{\circ} 29^{\prime} 29^{\prime \prime} \mathrm{S} 79^{\circ} 59^{\prime} 40^{\prime \prime} \mathrm{W}\right), 17 \mathrm{~m}$ a.s.l., Province of El Oro, listed in the bottom sediments (López-Blanco, Sinev, 2016).

Taxonomical remarks. This taxon was initially described from Brazil (Sinev et al., 2004). Recently, the Alona dentifera group was moved to the genus Magnospina Sousa, ElmoorLoureiro et Santos, 2016. However, it was separated from Coronatella, with unclear diagnosis, and the combination may change again. This Neotropical taxon ("Alona" dentifera) is well defined and occurs from U.S.A to Argentina (Sinev et al., 2004; Sousa et al., 2016).

(16) Notoalona sculpta (Sars, 1901)

Records. Coastal Region: Lake Tembladera $\left(3^{\circ} 29^{\prime} 29^{\prime \prime} \mathrm{S} 79^{\circ} 59^{\prime} 40^{\prime \prime} \mathrm{W}\right), 17 \mathrm{~m}$ a.s.l., Province of El Oro, listed based on based on fragments found in lake sediments (López-Blanco, Sinev, 2016).

Taxonomical remarks. This is a clearly recognizable Neotropical taxon initially described from Brazil (Rajapaksa, Fernando, 1987; Van Damme et al., 2013).

(17) Oxyurella longicaudis (Birge, 1910)

Records. Coastal Region: Lake Tembladera $\left(3^{\circ} 29^{\prime} 29^{\prime \prime} \mathrm{S} 79^{\circ} 59^{\prime} 40^{\prime \prime} \mathrm{W}\right), 17 \mathrm{~m}$ a.s.l., Province of El Oro based on fragments found in lake sediments (López-Blanco, Sinev, 2016).

Remarks. O. longicaudis is a common Neotropical species initially described from unknown localities in South America (ElmoorLoureiro, 1998; Van Damme, Dumont, 2010).

(18) Paralona pigra (Sars, 1862)

Records. Andean Region: Lakes of National Park Cajas $\left(2^{\circ} 50^{\prime} 00^{\prime \prime} \mathrm{S} 79^{\circ} 10^{\prime} 00^{\prime \prime} \mathrm{W}\right), 3.160$
4.450 m a.s.1., Province of Azuay (Alonso et al., 2017).

Taxonomical remarks. P. pigra was initially described from Norway; it is a cosmopolitan species (Dumont, Smirnov, 1996; Smirnov, 1996) and needs to be revised worldwide.

\section{Discussion}

The checklist of recorded species of Ecuadorian cladocerans contains 34 valid species. The number of cladoceran species of Ecuador recorded to date is significantly lower when compared to those in checklists for other countries in South America, such as Peru (88 taxa), Colombia (101 taxa), Brazil (116 taxa) and Venezuela (115 taxa) (Valdivia Villar, 1988; Elmoor-Loureiro, 2000; Zoppi de Roa, López, 2008; Kotov, Fuentes-Reinés, 2015). The comparably "low" biodiversity of the cladocerans in Ecuadorian water bodies is herein considered an artifact resulting from insufficient past efforts in sampling and identification. However, there is a benefit from the low number of studies on Cladocera in Ecuador: the taxonomical confusion is small and has not accumulated over decades (or even centuries). It is possible to start from a firm and modern taxonomical basis and conduct new studies in the region.

Several taxa in this checklist may belong to undescribed species, or to groups of which the taxonomy needs to be resolved in detail in the Neotropics or worldwide. The checklist illustrates that we should be careful to apply "Holarctic" names to Neotropical populations in Ecuador, including in high altitudes. However, we should be realistic that also "Löffler Islands" — tropical high altitude aquatic habitats harboring relict populations originating from northern latitudes (Van Damme, Eggermont, 2011) could be found in Ecuador. In addition, the possibility of true human-mediated introductions should not be excluded. It is clear however, that the majority of records deserve a closer look and a morphological and genetic comparison to populations from the terra typica.

Taxonomical studies of freshwater Cladocera in Ecuador are just starting and most of the 
efforts have been carried out in the limnetic zones of lakes and ponds in the Andean Region. Habitats important for cladoceran biodiversity, such as littoral zones, temporary pools and swamps, as well as several areas such as the low and medium altitudes of Ecuador, should be explored. The water bodies of the lowlands of the Coastal Region and Galápagos Islands have been scarcely studied and those of the Amazonian Region remain unexamined (Fig. 1). According to Green (1995), high altitude lakes have lower biodiversity than water bodies from lowlands (but see Van Damme, Eggermont, 2011), yet a high endemism can be expected in the Andes (Kotov et al., 2010). Therefore, more extensive studies of cladocerans, including the unexplored lowlands, and further explorations in the mountains with unique taxa, are necessary to improve such a situation. In addition, it will be interesting to learn what the volcanic Galápagos really harbor of cladoceran faunas. Despite a relatively small country in comparison to its neighboring countries, Ecuador has also an enormous biodiversity as a result of the heterogeneity of existing environments and the notorious altitudinal gradients. The diversity in habitats is currently not reflected in the Cladocera.

Presently, any attempts to analyze the distributional patterns of Cladocera in Ecuador would be uninformative due to the scarcity of adequate information. The occurrence of Cladocera species that are common in the Neotropics and that are known for example in Colombia and Peru, as well as new species, can be expected, especially in the diverse family Chydoridae. The description of new chydorids from Ecuador (Alonso, Kotov, 2017; Alonso, Sinev, 2017) clearly point in that direction, yet new taxa in other families cannot be excluded.

\section{Recommendations}

The low number of Cladocera species reported from Ecuador could be attributed to the insufficient number of cladoceran surveys and studies. More taxonomical and biogeographical studies of Ecuadorian cladocerans are needed, especially in regions which are poorly studied, such as the Amazonian Region, Coastal Region and Galápagos Islands (Fig. 1). These field surveys must encompass littoral zones of large lakes and ponds, particularly where macrophytes are present. Special attention should be paid to sampling in the bottom layers and in-shore areas and among macrophytes in order to survey the species that live in these zones. Also, it is necessary to sample a greater variety of aquatic habitats, such as artificial reservoirs, wetlands, swamps, "albarradas" (cisterns), inundated rice fields, temporary pools, moss, flooded forest, hyporheic/phreatic zones and phytotelmata communities. The efforts of local specialists should be combined with taxonomical training under the leadership of trained experts in order to provide knowledge transfer on taxonomy of cladocerans. The analysis of biodiversity of resting eggs from sediments using the Sars' Method (Van Damme, Dumont, 2010) may be used complementary to obtain a better estimation of biodiversity of cladocerans, to describe different life stages (e.g. males) and provide material for molecular studies.

In concordance with recent advances in the field, these studies must be reinforced by genetics, in order to accurately explore the genetic isolation between populations from different regions of the world, and within the region.

\section{Acknowledgements}

Corrections and suggestions from anonymous referees greatly improved an early version of the manuscript. Special thanks to Dr F.D.R Sousa for his valuable comments on some species and help with some bibliographical references and Dr A.Y. Sinev for some critical comments. Thanks for M. Belén López for help with the figure and L. Dávalos-Lind for revision of the English spelling and grammar in earlier draft.

Manuscript writing (remarks on taxonomic status of some tropical taxa revealed in Ecuador, general text editing) for ANN was funded by RFBR according to the research project 18 34-00389 мол_а. AAK was supported by Russian Government Program of Competitive Growth of Kazan Federal University. 


\section{References}

Adamowicz S.J., Hebert P.D.N., Marinone M.C. 2004. Species diversity and endemism in the Daphnia of Argentina: a genetic investigation // Zoological Journal of the Linnean Society. Vol.140. P.171-205.

Alonso M. 1996. Crustacea, Branchiopoda. Fauna Iberica 7. Crustacea Branchiopoda. Madrid: Museo Nacional de Ciencias Naturales. Consejo Superior de Investigaciones Científicas. 486 p.

Alonso M., Kotov A.A. 2017. A new species Alonella Sars, 1862 (Crustacea: Cladocera: Chydoridae) from Ecuadorian Andes // Zootaxa. Vol.4290. No.3. P.581590.

Alonso M., Sinev A.Yu. 2017. Relocation of Alona manueli Sinev \& Zawisza, 2013 and a new closely related species from the Ecuadorian Andes to the new genus Alpinalona (Cladocera, Chydoridae, Aloninae)//Zootaxa. Vol.4350. No.3. P.563-573.

Alonso M., Mosquera P., Hampel H., Vázquez R. 2017. Branquiópodos de las masas de agua lacustres del Parque Nacional Cajas (Andes Australes, Ecuador): inventario y notas autoecológicas // Maskana. Vol.8. No.1. P.71-74.

Bekker E.I., Karabanov D.P., Galimov Y.R., Kotov A.A. 2016. DNA barcoding reveals high cryptic diversity in the North Eurasian Moina species (Crustacea: Cladocera) // PLoS ONE. Vol.11. No.8. e0161737.

Belyaeva M., Taylor D.J. 2008. Cryptic species within the Chydorus sphaericus species complex (Crustacea: Cladocera) revealed by molecular markers and sexual stage morphology // Molecular Phylogenetics and Evolution. Vol.50. P.534-546.

Benzie J.A.H. 2005. The genus Daphnia (including Daphniopsis) (Anomopoda: Daphniidae). Guides to the identification of the microinvertebrates of the continental waters of the world Vol.21. Leiden: Kenobi Productions, Ghent and Backhuys Publishers. 376 p.

Brehm V. 1956. Cladocera aus Venezuela // Gessner F., Vareschi V. (Hrsg.). Ergebnisse der Deutschen Limnologischen. Venezuela Expedition 1952. S.217-232.

Briones C. 2012. Estudio preliminar de la diversidad de Cladóceros en el Lago Chongón, Guayas (Bachelor's thesis). Guayaquil-Ecuador: Universidad de Guayaquil. $51 \mathrm{p}$.

Casallas J., Gunkel G. 2001. Algunos aspectos limnologicos de un lago altoandino: El Lago San Pablo, Ecuador // Limnetica. Vol.20. No.2. P.215-232.

Chatterjee T., Kotov A.A., Van Damme K., Chandrasekhar S.V.A., Padhye S. 2013. An annotated checklist of the Cladocera (Crustacea: Branchiopoda) from India // Zootaxa. Vol.3667. No.1. P.1-89.

Colinvaux P., Steinitz-Kannan M. 1980. Species richness and area in Galapagos and Andean lakes: equilibrium phytoplankton communities and a paradox of the zooplankton // Kerfoot W.C. (ed.). Evolution and ecology of zooplankton communities. Hanover, New Hampshire: University Pressof New England. P.697712.
De los Ríos Escalante P., Kotov A.A. 2015. A checklist of Branchiopoda (Anostraca and Cladocera) of Chilean continental waters // Zootaxa. Vol. 4027. No.3. P.366388.

Crease T.J., Omilian A.R., Costanzo K.S., Taylor D.J. 2012. Transcontinental phylogeography of the Daphnia pulex species complex // PLoS ONE. Vol.7. No.10. e46620.

Debastiani-Júnior J.R., Elmoor-Loureiro L.M.A., Nogueira M.G. 2015. High taxonomic resolution as a determinant on finding new species and new records in the Río de La Plata basin: a case on Chydoridae (Crustacea: Branchiopoda: Cladocera) // Nauplius. Vol.23. No.1. P.21-30.

Delachaux T. 1919. Cladocères des Andes Pèruviennes // Mémoires de la Société Neuchâteloise des Sciences Naturelles. Vol.43. P.18-38.

Dumont H.J., Smirnov N.N. 1996. Reinstatement of the genus Paralona Šrámek-Hušek et al., 1962, and assessment of morphological variability in the Paralona pigra-group // Hydrobiologia. Vol.333. P.29-36.

Elías-Gutiérrez M., Ciros-Pérez J., Suárez-Morales E., Silva-Briano M. 1999. The freshwater Cladocera (Orders Ctenopoda and Anomopoda) of Mexico, with comments on selected taxa // Crustaceana. Vol.72. No.2. P.171-186.

Elías-Gutiérrez M., Martínez Jerónimo F., Ivanova N.V., Valdez Moreno M., Hebert P.D.N. 2008. DNA barcodes for Cladocera and Copepoda from Mexico and Guatemala, highlights and new discoveries // Zootaxa. Vol.1839. P.1-42.

Elmoor-Loureiro L.M.A. 1998. Branchiopoda. Freshwater Cladocera // Young P.S. (ed.). Catalogue of Crustacea of Brazil. Rio de Janeiro: Museu Nacional. (Série Livros No. 6). P.15-41.

Elmoor-Loureiro L.M.A. 2000. Brazilian cladoceran studies: where do we stand? // Nauplius. Vol.8. No.1. P.117-131.

Elmoor-Loureiro L.M.A. 2002. Occurrence of Kurzia polyspina Hudec (Crustacea, Anomopoda, Chydoridae) in Brazil // Revista Brasileira de Zoologia. Vol.19. No.1. P.305-307.

Elmoor-Loureiro L.M.A. 2018. Cladóceros do Brasil: Famílias Chydoridae e Eurycercidae. Available at: https://cladocera.wordpress.com

Flössner D. 2000. Die Haplopoda und Cladocera (ohne Bosminidae) Mitteleuropas. Leiden: Backhuys. $428 \mathrm{~S}$.

Gauthier H. 1939. Contribution à l'étude de la Faune Dulçaquicole de la région du Tchad et particulièrement des branchiopodes et des ostracodes // Bulletin de 1'Institut Français d'Afrique Noire. Vol.1. No.1. P.110-244.

Green J. 1995. Altitudinal distribution of tropical planktonic Cladocera // Hydrobiologia. Vol.307. P.75-84.

Gunkel G. 2000. Limnology of an equatorial high mountain lake in Ecuador, Lago San Pablo // LimnologicaEcology and Management of Inland Waters. Vol.30. No.2. P.113-120.

Hebert P.D.N., Witt, J.D.S., Adamowicz S.J. 2003. Phylogeographical patterning in Daphnia ambigua: Region- 
al divergence and intercontinental cohesion // Limnology and Oceanography. Vol.48. No.1. P.261-268.

Huang X., Shi X., Kotov A.A., Gu F. 2014. Confirmation through genetic analysis of the existence of many local phyloclades of the genus Simocephalus (Crustacea, Cladocera) in China // PLoS ONE. Vol.9. No.11. e112808.

Hudec I. 2000. Subgeneric differentiation within Kurzia (Crustacea: Anomopoda: Chydoridae) and a new species from Central America // Hydrobiologia. Vol.421. P.165-178.

Iglesias C., Bonecker C., Brandão L., Crispim M.C., Eskinazi-Sant'Anna E.M., Gerhard M., Laço Portinho J., Maia-Barbosa P., Panarelli E., Santangelo J.M. 2016. Current knowledge of South American cladoceran diapause: A brief review // International Review of Hydrobiology. Vol.101. No. 3-4. P.91-104.

Ihering H. 1895. Os Crustaceos phyllopodes do Brazil // Revista do Museo Paulista. Vol.1. P.165-180.

Jeong H., Kotov A.A., Lee W. 2014. Checklist of the freshwater Cladocera (Crustacea: Branchiopoda) of South Korea // Proceedings of the Biological Society of Washington. Vol.127. No.1. P.216-228.

Ji G.H., Xiang X.F., Chen S.Z., Yu G.L., Kotov A.A., Dumont H.J. 2015. Annotated Checklist of Chinese Cladocera (Crustacea: Branchiopoda). Part II. Order Anomopoda (families Macrotrichidae, Eurycercidae and Chydoridae) // Zootaxa. Vol.4044. No.2. P.241269.

Johnson D.S. 1953. On some Cladocera from South African muds // Annals and Magazine of Natural History. Ser.12. Vol.6. No.72. P.923-928.

Korovchinsky N.M. 1992. Sididae \& Holopediidae (Crustacea: Daphniiformes) // Guides to the identification of the microinvertebrates of the continental waters of the world. Vol.3. The Hague: SPB Academic Publishing. $82 \mathrm{p}$.

Korovchinsky N.M. 2004. [Cladocerans of the order Ctenopoda of the world fauna (morphology, taxonomy, ecology, biogeography)]. Moscow: KMK Sci. Press. 410 p. [In Russian].

Korovchinsky N.M. 2013. Cladocera (Crustacea: Branchiopoda) of South East Asia: history of exploration, taxon richness and notes on zoogeography // Journal of Limnology. Vol.72. No.S2. P.109-124.

Kotov A.A., 2007. Revision of the hirsuticornis-like species of Macrothrix Baird, 1843 (Cladocera: Anomopoda: Macrothricidae) from Subantarctic and temperate regions of the southern hemisphere // Journal of Natural History. Vol.41. Nos.41-44. P.2569-2620.

Kotov A.A. 2015. A critical review of the current taxonomy of the genus Daphnia O.F. Müller, 1785 (Anomopoda, Cladocera) // Zootaxa. Vol.3911. No.2. P.184-200.

Kotov A.A. 2016. Faunistic complexes of the Cladocera (Crustacea, Branchiopoda) of Eastern Siberia and the Far East of Russia // Biology Bulletin. Vol.43. No.9. P.970-987.

Kotov A.A., Dumont H.J. 2000. Analysis of the Ilyocryptus spinifer-species group (Anomopoda, Branchiopo- da), with description of a new species // Hydrobiologia. Vol.428. No.1. P.85-113.

Kotov A.A., Fuentes-Reinés J.M. 2015. An annotated checklist of the Cladocera (Crustacea: Branchiopoda) of Colombia // Zootaxa. Vol.4044. No.4. P.493-510.

Kotov A.A., Śtifter P. 2006. Cladocera: Family Ilyocryptidae (Branchiopoda: Cladocera: Anomopoda) // Guides to the identification of the microivertebrates of the Continental Waters of the world. Vol.22. Leiden: Kenobi Productions, Ghent and Backhuys Publishers. 172 p.

Kotov A.A., Taylor D.J. 2010. A new African lineage of the Daphnia obtusa group (Cladocera: Daphniidae) disrupts continental vicariance patterns // Journal of Plankton Research. Vol.32. No.6. P.937-949.

Kotov A.A., Sinev A.Yu., Berrios V.L. 2010. The Cladocera (Crustacea: Branchiopoda) of six high altitude water bodies in the North Chilean Andes, with discussion of Andean endemism// Zootaxa. Vol.2430. No.1. P. $1-66$.

Kotov A.A., Forró L., Korovchinsky N.M., Petrusek A. 2013. World checklist of freshwater Cladocera species. Available from: https://fada.biodiversity.be/ group/show/17

Kotov A.A., Karabanov D.P., Bekker E.I., Neterina T.V., Taylor D.J. 2016. Phylogeography of the Chydorus sphaericus group (Cladocera: Chydoridae) in the Northern Palearctic // PLoS ONE. Vol.11. No.12: e0168711. doi:10.1371/journal.pone.0168711

Labaj A.L., Michelutti N., Smol J.P. 2017. Changes in cladoceran assemblages from tropical high mountain lakes during periods of recent climate change // Journal of Plankton Research. Vol.39. No.2. P.211-219.

López C. 1993. Primer registro de Ephemeroporus acanthodes Frey 1982 (Crustácea: Cladócera) para Venezuela // Acta Científica Venezolana. Vol.44. P.312314.

López-Blanco C., Sinev A.Yu. 2016. Cladocera biodiversity in la Tembladera Lake (Ecuador): a palaeolimnological approach // Crustaceana. Vol.89. No.14. P.1611-1637.

Matsumura-Tundisi T. 1984. Occurrence of species of the genus Daphnia in Brazil // Hydrobiologia. Vol.112. No.3. 161-165.

Obando R. 2009. Evaluación de los parámetros físicoquímicos y biológicos de la Laguna El Junco antes, durante y después de la erradicación de la tilapia (Oreochromis niloticus), Isla de San Cristóbal, Galápagos. Bachelor's thesis. Ecuador: Universidad del Azuay. 77 p.

Orlova-Bienkowskaja M.Y. 2001. Daphniidae: genus Simocephalus // Guides to the identification of the microinvertebrates of the continental waters of the World. Vol.17. Leyden: Backhuys. 130 p.

Paggi J.C. 1980. Aportes al Conocimiento de la fauna Argentina de Cladoceros. II. Euryalona fasciculata Daday, 1905 y Euryalona occidentalis Sars, $1901 / /$ Rev. Asoc. Cienc. Nat. Literal. Vol.11. P.145-160.

Petrusek A., Èerny M, Audenaert E. 2004. Large intercontinental differentiation of Moina micrura (Crustacea: 
Anomopoda): one less cosmopolitan cladoceran? // Hydrobiologia. Vol.526. P.73-81.

Petrusek A., Hob ¿k A., Nilssen J.P., Skage M., Èerný M., Brede N., Schwenk K. 2008. A taxonomic reappraisal of the European Daphnia longispina complex (Crustacea, Cladocera, Anomopoda) // Zoologica Scripta. Vol.37. P.507-519.

Popova E.Y., Kotov A.A. 2013. Latitudinal patterns in the diversity of two subgenera of the genus Daphnia O.F. Müller (Crustacea: Cladocera: Daphniidae) // Zootaxa. Vol.3736. No.2. P.159-174.

Quimi G.M. 2014. Composición y abundancia del zooplancton en la Represa San Vicente, Comuna Las Balsas, durante junio - noviembre del 2013, Santa Elena, Ecuador. Tesis de grado. Universidad Estatal Peninsula de Santa Elena, Ecuador. 71 p. http:// repositorio.upse.edu.ec/handle/46000/1874

Rajapaksa R., Fernando C.H. 1987. Redescription and assignment of Alona globulosa Daday, 1898 to a new genus Notoalona and a description of Notoalona freyi sp. nov. // Hydrobiologia. Vol.144. P.131-153.

Sars G.O. 1885. On some Australian Cladocera, raised from dried mud // Forhandlinger i Videnskabs-Selskabet i Christiania. Vol.8. P.1-46.

Sars G.O. 1901. Contributions to the knowledge of the fresh-water Entomostraca of South America, as shown by artificial hatching from dried material. 1. Cladocera // Archiv for Mathematik og Naturvidenskab. Vol.23. No.3. P.1-102.

Serafim J.M., Lansac-Tôha F.A., Paggi J.C., Velho L.F.M., Robertson B. 2003. Cladocera fauna composition in a river-lagoon system of the upper Paraná River floodplain, with a new record for Brazil // Brazilian Journal of Biology. Vol.63. No.2. P.349-356.

Sharma P. 2014. Morphological and molecular identification of three Ceriodaphnia species (Cladocera: Daphniidae) from Australia // Advances in Zoology. Article ID 258134. $14 \mathrm{p}$.

Sharma P., Kotov A.A. 2013. Molecular approach to identify sibling species of the Ceriodaphnia cornuta complex (Cladocera: Daphniidae) from Australia with notes on the continental endemism of this group // Zootaxa. Vol.3702. No.1. P.79-89.

Sinev A.Yu. 1997. Review of the affinis-group of Alona Baird, 1843, with the description of a new species from Australia (Anomopoda Chydoridae) // Arthropoda Selecta. Vol.6. Nos.3-4. P.47-58.

Sinev A.Yu. 1998. Alona ossiani sp.n., a new species of the Alona affinis complex from Brasil, deriving from the collection of G. O. Sars (Anomopoda Chydoridae) // Arthropoda Selecta. Vol.7. No.2. P.103-110.

Sinev A.Yu. 2001. Redescription of Alona glabra Sars, 1901, a South American species of the pulchellagroup (Branchiopoda: Anomopoda: Chydoridae) // Arthropoda Selecta. Vol.10. No.4. P.273-280.

Sinev A.Yu. 2004. Redescription of two species of the genus Leydigiopsis Sars, 1901 (Branchiopoda, Anomopoda, Chydoridae) // Invertebrate Zoology. Vol.1. No.1. P.75-92.

Sinev A.Yu. 2013. Cladocerans of Alona affinis group (Cladocera: Anomopoda: Chydoridae) from North America // Zootaxa. Vol. 3693. No.3. P.329-343.
Sinev A.Yu. 2015a. Revision of the pulchella-group of Alona s. lato leads to its translocation to Ovalona Van Damme et Dumont, 2008 (Branchiopoda: Anomopoda: Chydoridae) // Zootaxa. Vol.4044. No.4. P.451492.

Sinev A.Yu. 2015b. Morphology and phylogenetic position of three species of genus Camptocercus Baird, 1843 (Cladocera: Anomopoda: Chydoridae) // Zootaxa. Vol.4040. No.2. P.169-186.

Sinev A.Yu., Elmoor-Loureiro L.M.A. 2010. Three new species of chydorid cladocerans of subfamily Aloninae (Branchipoda: Anomopoda: Chydoridae) from Brazil // Zootaxa. Vol.2390. P.1-25.

Sinev A.Yu., Zawisza E. 2013. Comments on cladocerans of crater lakes of the Nevado de Toluca Volcano (Central Mexico), with the description of a new species, Alona manueli sp. nov // Zootaxa. Vol.3647. No.2. P.390-400.

Sinev A.Yu., Kotov A.A., Van Damme K. 2004. Morphology of a Neotropical cladoceran Alona dentifera (Sars, 1901), and its position within the Chydoridae Stebbing, 1902 (Branchiopoda: Anomopoda) // Arthropoda Selecta. Vol.13. No.3. P.99-107.

Smirnov N.N. 1971. [Chydoridae of the world fauna] // Fauna SSSR. Rakoobraznie. Vol.1. Moscow: Nauka. 531 p. [In Russian].

Smirnov N.N. 1992. The Macrothricidae of the world. Guides to the identification of the microivertebrates of the Continental Waters of the world. Vol.1. The Hague: SPB Academic Publishing. 143p.

Smirnov N.N. 1996. Cladocera: the Chydorinae and Sayciinae (Chydoridae) of the world // Guides to the identification of the microivertebrates of the Continental Waters of the world. Vol.11. Amsterdam: SPB Academic Publishing. 197 p.

Sousa F.D.R., Elmoor-Loureiro L.M.A., Santos S. 2016. Position of the dentifera-group in the Coronatellabranch and its relocation to a new genus: Magnospina gen. n. (Crustacea, Chydoridae, Aloninae) // ZooKeys. Vol.586. P.95-119.

Steere W. 1950. The phytogeography of Ecuador // Studies in Ecuador Geography. Vol.15. P.83-86.

Stingelin T. 1913. Cladoceren aus den gebirgen von Kolombien. Memories de la Societe des Sciences Naturales de Neuchatel. Vol.5. P.600-638.

Taylor D.J., Finston T.L., Hebert P.D.N. 1998. Biogeography of a widespread freshwater crustacean: pseudocongruence and cryptic endemism in the North American Daphnia laevis complex // Evolution. Vol.52. No.6. P.1648-1670.

Torres L.E., Rylander K. 2006. Diversity and abundance of littoral cladocerans and copepods in nine Ecuadorian highland lakes // Revista de biología tropical. Vol.54. No.1. P.131-137.

Valdivia Villar R.S. 1988. Lista de Cladóceros dulceacuícolas del Perú // Amazoniana. Vol.10. No.3. P.283297.

Van Colen W.R., Mosquera P., Vanderstukken M., Goiris K., Carrasco M.C., Decaestecker E., Alonso M., LeónTamariz F., Muylaert K. 2017. Limnology and trophic 
status of glacial lakes in the tropical Andes (Cajas National Park, Ecuador)//Freshwater Biology. Vol.62. No.3. P.458-473.

Van Damme K., Eggermont H. 2011. The Afromontane Cladocera (Crustacea: Branchiopoda) of the Rwenzori (Uganda-D. R. Congo): taxonomy, ecology and biogeography // Hydrobiologia. Vol.676. P.57-100.

Van Damme K., Dumont H.J. 2010. Cladocera of the Lençóis Maranhenses (NE-Brazil): faunal composition and a reappraisal of Sars' Method // Brazilian Journal of Biology. Vol.70. No.3. P.755-779.

Van Damme K., Sinev A.Yu. 2013. Tropical AmphiPacific disjunctions in the Cladocera (Crustacea: Branchiopoda) // Journal of Limnology. Vol.72. No.s2. P.209-244.

Van Damme K., Kotov A.A., Dumont H.J. 2010. A checklist of names in Alona Baird 1843 (Crustacea: Cladocera: Chydoridae) and their current status: an analysis of the taxonomy of a lump genus // Zootaxa. Vol.2330. P.1-63.

Van Damme K., Maiphae S., Sa-ardrit P. 2013. Inland swamps in South East Asia harbour hidden cladoceran diversities: species richness and the description of new paludal Chydoridae (Crustacea: Branchiopoda: Cladocera) from Southern Thailand // Journal of limnology. Vol.72. No.s2. P.174-208.

Villalobos L. 1994. Distribution of Daphnia in high mountain and temperate lakes of South America // Internationale Vereinigung für theoretische und angewandte Limnologie. Vol.25. No.4. P.2400-2404.

Xiang X.F., Ji G.H., Chen S.Z., Yu G.L., Xu L., Han B.P., Kotov A.A., Dumont H.J. 2015. Annotated Checklist of Chinese Cladocera (Crustacea: Branchiopoda). Part I. Haplopoda, Ctenopoda, Onychopoda and Anomopoda (families Daphniidae, Moinidae, Bosminidae, Ilyocryptidae) // Zootaxa. Vol.3904. No.1. P.1-27.

Zoppi de Roa E., López C. 2008. An updated checklist of inland Cladocera (Crustacea: Orders Ctenopoda and Anomopoda) from Venezuela // Zootaxa. Vol.1919. P.45-57.

Responsible editor K.G. Mikhailov 